\title{
Interdisciplinarity - the Basis for the Study and Teaching of International Relations
}

\author{
V. D. Kamynin \\ Department of Theory and History of International \\ Relations \\ Ural Federal University named after the First President of \\ the Russian Federation B.N. Yeltsin \\ Ekaterinburg, Russia \\ kamyninv@yandex.ru
}

\author{
N.V. Kozykina \\ Department of Theory and History of International \\ Relations \\ Ural Federal University named after the First President of \\ the Russian Federation B.N. Yeltsin \\ Ekaterinburg, Russia \\ april-chita@mail.ru
}

\begin{abstract}
The article considers the interdisciplinary approach as an interdependent system of knowledge integration, expressed in research and teaching of international relations. It is proved that the discipline of "International Relations" has gone through several stages in the implementation and development of other sciences methodologies to explain and study the evolution of international relations. The most influential ones are political science, history, sociology, but the achievements of the natural and exact sciences are widely used. At the same time, there is a discourse between political science and historical approaches to the analysis of international relations. This is especially pronounced both in the field of theory and in research methods.
\end{abstract}

Keywords - international relationships; interdisciplinarity; multidisciplinarity; scientific research; education

\section{INTRODUCTION}

International relations as a combination of economic, political, legal, ideological, diplomatic, military, cultural and other ties and relationships between entities operating in the international sphere have existed since the emergence of states, but as a scientific and educational discipline "International Relations" is a relatively young discipline. It appeared exactly 100 years ago, when departments and research centers to study international relations were established in a number of British and American universities after the end of the First World War. The reason for this emergence was the desire of scientists to explain (emphasized by us - V.K. and N.K.) such questions as - why do wars begin; what should be done to prevent international conflicts; due to what reasons does the role of powers in the world arena change?

What are the reasons for the use of interdisciplinarity in the study of international relations? In order to successfully describe the above-mentioned processes, the theories were to be formulated, but the time to create their own theories was not enough. And after 10 years the world was drawn into a series of protracted military conflicts, and after 20 years the Second World War began. So the scientists could take advantage only of copying conceptual and categorical patterns already available in other scientific disciplines that had greater traditions in the understanding of current international events. In our opinion, those were political and historical sciences whose influence on the evolution of the discipline's methodology was most vivid.

We also assume that another reason of spreading the interdisciplinary idea in the subject lies in the fact that international relations as an independent scientific discipline began to take shape simultaneously with the next Scientific Revolution, which occurred in the second half of the 20th century. By the time the transition from specialization and fragmentation of sciences to the synthesis of philosophy, history and natural sciences took place, which led to the development of interdisciplinary research methodologies.

\section{METHODS AND MATERIALS}

The study of interdisciplinarity in research and teaching is carried out by many researchers. It is important for us to differentiate such approaches to understanding interdisciplinarity of international relations in science and education.

The concept of interdisciplinarity of international studies as a scientific discipline is mentioned together with the terms of transdisciplinarity and multidisciplinarity. It is quite obvious that, despite the differences in these definitions, all of them, one way or another, express various aspects of interaction of several disciplines.

It is believed that, on the one hand, "International Relations" is an interdisciplinary subject that combines many disciplines involved in its creation and development. On the other hand, "International Relations" is not an interdisciplinary subject, since the discipline belatedly absorbed many new ideas and approaches that changed the social sciences between the 1960s and 1980s [1].

It is completely obvious to us that international relations can be both of these things. This is connected with the changing history of the development of the scientific discipline itself, which in its formation went through three separate stages, each of which had a profound influence on its attitude to interdisciplinarity. 


\section{RESULTS}

Interdisciplinarity in the study and teaching of international relations expands not only the heuristic possibilities of this scientific and educational discipline, but also leads to acute discourse in the interpretation of main categories of international relations.

\section{DISCUSSION}

Discourse is on the interpretation of the main categories of international relations

The theoretical arsenal of political science turned out to be extremely popular in the context of the formation of international relations explanatory concepts. Since the time of Plato and Aristotle, the main attention of researchers in the political sphere of human life has been focused on the state, government and power relations.

Being a part of the political sphere, foreign policy is formed as a result of the interaction of a wide range of domestic political factors and international processes and requires the application of modern political science approaches to the analysis of international relations, the focus of which is placed at the junction of political and international theory.

The basic theories explaining the nature and development of international relations - political liberalism, political realism, and Marxism-Leninism - arose from the need to comprehend the practice of political struggle in the international arena associated with the outcomes of the First and Second World Wars. The liberal paradigm that prevailed in the interwar period was the basis for documents aimed at preventing the Second World War. Political realism and Marxism-Leninism were an attempt to comprehend the political realities of the Cold War. The main discourse throughout the twentieth century occurred between the liberal and realistic paradigms, which led to three "big debates" in the theory of international relations. Despite attempts to accept some of the arguments of ideological opponents in the interpretation of international relations, and the emergence of new political realities, especially globalization, the main differences along which the main paradigms diverge continue to persist.

At the same time, researchers note that a broad historical understanding of international relations remains an important area of work for various schools [2].

Discourse on the methods is used by the discipline of "International Relations"

There is a wide and diverse range of methods in international relations research. They are usually divided into general scientific, interdisciplinary and special ones. Their use helps to solve a number of scientific problems.

Firstly, methods aimed at obtaining and processing information. In the first case, methods of observation, measurement, comparison and description are used, in the second case - experts survey or, most often, textual analysis.
Secondly, in order to answer such pressing questions (In which direction will this or that international political process develop? Is it possible to prevent an undesirable course of events? How to direct them in the right direction that meets the interests of specific political forces?) an expert makes use of political analysis and forecasting methods.

The discipline of "World Politics" emerged later than the discipline of "International Relations", but it already has its own methodology for studying the processes of making and implementing decisions which affect the life of the world community. Methods of this subject are also key research methods for international relations.

Methods of sociological science are extremely popular in international relations in the context of historical materials synthesis. French philosopher, sociologist and political scientist R. Aron gave an example of the classical use of the historical and sociological method in international political research. The application of this method allowed us to introduce the concept of "a system of international relations" as a complex of relationships between members of the international community, based on the interaction of heterogeneous factors, the most important of which is the ratio of the combined potentials of individual participants and the hierarchy built on it (mutual position of countries), as well as principles and the rules of this relationship. Applying his approach to the study of international relations, R. Aron was able to predetermine a large number of upcoming changes in world politics, starting with the collapse of communist ideology, the transition to a post-industrial society and ending with a change in the meaning of sovereignty in nation-states. The predictive capabilities of the method are still not being revised and lead to its use in theoretical analysis of international realities.

Among the interdisciplinary methods of studying international relations, the methods of historical science are often used: comparative-historical, historical-genetic retrospective, historical-typological, chronological methods

Methods of psychological science are actively used to analyze the process of political decision making. In particular behaviorism - the initial methodological statement of which is that the nature of power and politics is derived from the nature of man, which is possible to be studied by scientific methods.

Special (applied) methods also came from other sciences. They are divided into 3 groups: situation analysis methods (observation, study of documents, comparison); explicative (quantitative) methods (content analysis, event analysis, cognitive mapping); prognostic methods (conclusions by analogy, the method of simple extrapolation, the Delphic method, scenario building, etc.)

Discourse on sources is as follows.

Reliance on sources is a fundamental principle of scientific research. An acute discourse appears between political and historical approaches. In political science, primary (documents) and secondary (literature) sources of information are distinguished. Historians fundamentally separate these two levels of obtaining information, referring only documents to sources. 
One of the special historical disciplines - source studies - is developing methods of scientific criticism of sources and obtaining from them reliable and representative information about the studied object. However, the use of sources in historical research is complicated by the fact that the very concept of "source" in source studies is interpreted ambiguously. There are various definitions of this concept, the main difference between which is located between the two approaches. The first approach is that the source reflects historical reality and the researcher, having proved the authenticity of the document, can safely include the information contained in it in his scientific research. A diametrically opposite approach considers the source as a "realized product of the human psyche" and requires the researcher to enter into dialogue with the author of the source to obtain authentic information about the object of study. In historical science, the genre of problematic source studies is extremely developed, in which, using the example of various complexes of sources, the methodology of external and internal criticism of historical documents is tested [3].

Discourse on historiography is the following.

Literature in historical research is used not so much to extract the information contained in it as to, firstly, show the degree of knowledge of the problem, and, secondly, to enter into polemics with predecessors on the issue under study. A special branch of historical knowledge - historiography - is developing a methodology for the scientific criticism of literature. The main thing in the analysis of literature is to identify the methodological preferences of the author of the study, which are very strongly influenced not only by the worldview of the author, but also by the environment in which the study is written (public order). The modern literature on international relations is multi-conceptual, that is, it contains different points of view due to the author's theoretical positions: realists, liberals, communists, Eurasians, geopoliticianss, globalists, etc.

The existence of literature written from various theoretical perspectives is normal in a modern pluralistic society. In a scientific study, an international historian can use works that correspond to his worldview positions, and give criticism of works with the ideological principles of the authors of which he does not agree.

"Three Ages" of International Relations in the context of Interdisciplinarity

The science of international relations began to take shape quite late. Until the beginning of the twentieth century, understanding of international politics was the destiny of diplomats and the military, or those who only criticized the established order of the balance of power in Europe at the end of the 19th century. But these critics were not researchers of international relations. The First World War served as a catalyst for the development of "International Relations" as an independent academic discipline, and in 1919, when the Treaty of Versailles was signed and the League of Nations was formed. The first ever department of international politics named after Woodrow Wilson was opened in Aberystwyth University in Wales. Despite of the use of the term "international politics", this university department was far from political science. But this was the first stage in the formation of international relations as a science, which used methods and approaches from other disciplines, which made it possible to get an idea of the problems of international relations of that time (problems of war and peace; the problem of the state and the idea of international government; international integration and democratization of diplomacy). The explanation of these problems was the very means by which various disciplinary methods were combined into a common language that was understandable to the then emerging world community. In the first few decades of its existence, until the 1950s, international relations were essentially a transdisciplinary subject with a very limited attachment to political science. In part, this was the result of the dominance of the British school in international studies of the time.

Transdisciplinarity is treated differently. For some, it requires a common theoretical foundation [4]. Others relate this concept to scientific imperialism [5]. For the third, transdisciplinarity means that methods and theoretical approaches come from different disciplines, but form a coherent structure and problems [6]. So transdisciplinarity in our context is interpreted precisely in the first version of the definition of this phenomenon.

The development of international research in the USA after World War II changed the orientation of the discipline and opened the second stage in the development of the relationship of international research to interdisciplinarity. American scholars have studied international relations as political scientists, using political science models as the basis for their understanding of the world. Interdisciplinarity was largely limited only to the use of historical data to support abstract models of the social sciences, which usually came into international relations through comparative political science. This was a period of realist dominance, as a result of which many of the theoretical innovations that hit social sciences in the 1950s, 1960s, and 1970s circumvented international relations (with the exception of liberal institutionalism, the structuralist Marxist approach, and the influence of microeconomics). It was the influence of political science on international relations that led to thirty years of isolation of the study of international relations, which remained a theoretically closed world and built their understanding of the world on abstract models, often built on assumptions unique to international relations [7]. The only thing that connected international relations with disciplines outside of political science was their relation to history. Historical examples were simplified and used to build and justify abstract system models. In turn, these models emphasized the transhistorical nature of "truths" about international relations in the context of realism. The most robust project of this type was the Correlates of War Project, an academic study of the history of hostilities that quantified the data of the two-century history of mankind, and then used this data to predict when the international system is more likely to lead to system-wide wars [8].

Once this isolation was destroyed, due to the loss of the dominance of realism, interdisciplinarity returned with renewed vigor and made up for lost time. The collapse of 
realistic domination in international relations opened the third stage and a return to interdisciplinarity, which centered around feminism, neo-Marxist theory, postmodernism and constructivism. Despite the fact that these paradigms are competing, they often use interdisciplinary approaches, try to synthesize the ideas used by different paradigms, or enter into debates about the meaning of different interdisciplinary concepts. The lack of consistent links between these critical paradigms and the more traditional paradigms of realism and liberalism means that international relations are still an interdisciplinary subject, since this interdisciplinarity runs parallel to liberal and realistic traditions that rarely interact with these approaches. But can we call this process just an interdisciplinary approach? Perhaps, this is a multidisciplinary approach [9].

Interdisciplinarity in the educational process is as follows.

Interdisciplinarity in science does not always coincide with interdisciplinarity in education. The appeal to the topic of interdisciplinarity in education is due to the deepening fragmentation of science, which complicates both the educational process itself and research exits at the level of practice-oriented projects that are directly related to innovative activities, including the development of innovative approaches to teaching science about international relations.

O.V. Zinevich and E.A. Ruzankin's consider that the main problem of establishing interdisciplinary relations in the practice of teaching academic disciplines is the allocation of leading disciplines that take on the function of the subject constructing of academic discipline. The authors believe that it is historical disciplines that should play a leading role in the design of the subject of regional studies [10].

From our point of view, the leading role in the teaching of international relations should be played by political and historical sciences, which took the most active role in the formation of the theoretical and methodological apparatus of this scientific discipline. It should also be taken into account that innovative textbooks that have been appearing recently in these sciences introduce innovative approaches, in particular, the principle of equal respect for all existing points of view has been proclaimed. At the same time, it is proved that criticism of one methodology from the perspective of another methodology is incorrect [11].

\section{CONCLUSION}

The modern science of international relations is characterized by close interaction with related humanitarian, natural and even exact mathematical sciences. The influence of interdisciplinarity is felt in everything: in theories that explain international events; in methodology for studying the actual material; in the use of information sources and their scientific criticism; in the scientific literature. Interdisciplinarity in international relations is not a tribute to fashion; it does not correspond only to the trend of modern science of science (doing science). The science of "international relations" has arisen and exists in conditions when international events are the object of study of various scientific disciplines, there are proven methods for their study and interpretation. The most powerful impact on international relations has always been political and historical sciences. However, the modern trend is international relations taxonomy as political science.

\section{References}

[1] Lucian M. Ashworth, "Interdisciplinarity and international relations", European Political Science, 8(1), pp. 16-25. March 2009

[2] Mironov V., "B. Buzan and the English School of International Relations", Bulletin of Tomsk State University, No. 438, pp.143-150, 2019.

[3] Kamynin V., Khramtsov A., "Minutes of meetings of municipal authorities as a historical source (based on materials from Western Siberia. 1870 - 1890)", Issues of history, No. 1, pp. 121 - 128, 2019

[4] P. van den Besselaar, G. Heimericks, "Disciplinarity, multidisciplinarity, interdisiciplinarity - concepts and indicators", Sydney, Australia, July 16-20 2001 [8th Conference on Scientometrics and Informetrics]. Retrieved from http://heimeriks.net/2002issi.pdf

[5] Long, D. Interdisciplinarity and the Englishschool of international relations // International Studies Association Annual Convention, New Orleans, 25-27 March 2002

[6] Lucian M. Ashworth, "Interdisciplinarity and international relations", European Political Science, 8(1), pp. 16-25. March 2009.

[7] Lucian M. Ashworth, "Interdisciplinarity and international relations", European Political Science, 8(1), pp. 16-25. March 2009.

[8] D. Armitage, "The fifty years' rift: intellectual history and international relations", Modern Intellectual History, No. 1, pp. 97-01, 2004

[9] Lucian M. Ashworth, "Interdisciplinarity and international relations", European Political Science, 8(1), pp. 16-25. March 2009.

[10] O. Zinevich, E. Ruzankina, "Regional Studies as a complex of research and educational disciplines in the perspective of interdisciplinarity, Comparative politics, No. 3 (17), pp. 159-167, 2014

[11] V. Zapariy, V. Kamynin, B. Lichman, "On the waves of our memory... Formation of dissent in Russian history textbooks (UGTU-UPI, early 90's)", Quaestio Rossica, vol. 7, No. 1, pp. 23-36, 2019. 